Research/Technical Note

\title{
Genetic Variability and Association Among Agronomic Characters in Selected Field Pea (Pisumsativum L.) Genotypes at Bale Zone, Sinana Research Center, Oromia Region, Ethiopia
}

\author{
Benti Ofga, Yohannis Petros \\ Department of Biology, Haramaya University, Haramaya, Ethiopia \\ Email address: \\ bentiofga@gmail.com (B. Ofga)
}

To cite this article:

Benti Ofga, Yohannis Petros. Genetic Variability and Association Among Agronomic Characters in Selected Field Pea (Pisumsativum L.) Genotypes at Bale Zone, Sinana Research Center, Oromia Region, Ethiopia. International Journal of Genetics and Genomics.

Vol. 5, No. 6, 2017, pp. 63-75. doi: 10.11648/j.ijgg.20170506.11

Received: March 29, 2017; Accepted: April 25, 2017; Published: November 11, 2017

\begin{abstract}
Field pea (Pisumsativum L.) is an annual herbaceous legume belonging to the family Fabaceae that adapted to cool moist climate with moderate temperature. The species P. sativumis dominant in Ethiopia even though wild and primitive forms are also known to exist in the high elevation of the country. No sufficient work has been done for understanding and describing the nature and extent of genetic variability on Field Pea. Thus use of genetic variability is suggested to alleviate the shortage of released varieties in Field pea. The studies of association characters solve the low yield of field pea in Ethiopia. Therefore, the present study was conducted to study genetic variability and association among agronomic characters of field pea (Pisumsativum L.) genotypes. The field experiment was conducted using 29 varieties and 7 accessions at Sinana Agricultural Research Centre during 2013/14 main growing season. Treatments were arranged in Simple Lattice design with two replications. The results obtained revealed that the mean squares of the genotypes were highly significant for most of the characters $(p<0.05)$ except for days to emergence, days to flowering, pods per plant, above ground biomass and harvest index implying that wide range of variability has been obtained for the traits studied. The genotypic coefficient of variation ranged from $2.91 \%$ for plant height to $37.9 \%$ for above ground biomass, while phenotypic coefficient of variation ranged from $6.28 \%$ for days to maturity to $62.6 \%$ for above ground biomass. The estimated broad sense heritability ranged from $6.9 \%$ for yield per plant to $93.0 .0 \%$ for pod length. Correlation between different traits and seed yield indicated that there was marked positive and highly significant association of seed yield with days to emergence $\left(\mathrm{rg}=0.296^{* *}\right)$, days to maturity $\left(\mathrm{rg}=0.184^{* *}\right)$, seeds per pod $\left(\mathrm{rg}=0.325^{* *}\right)$ and harvest index $\left(\mathrm{rg}=0.341^{* *}\right)$ indicating the yield improvement perhaps be contributed to changes in these traits. The path analysis at phenotypic level revealed that maximum positive direct effect was exerted by 100 seed weight (1.754) followed by pod length (2.211) and days to emergence (2.056). These traits best contributing to yield variation that emphasis by breeders for future yield improvement of the crop. It can be conclude that Field pea yield can be successfully improved by studying genetic variability and its agronomic characters.
\end{abstract}

Keywords: Genetic Advance, GCV, Heritability, PCV, Pisumsativum, Variability

\section{Introduction}

Field pea (Pisumsativum L.) is an annual herbaceous legume belonging to the family Fabaceae that adapted to cool moist climate with moderate temperature. It is the second most important stable cool-season food legume among the highland pulses in rural Ethiopia. Field pea produced in various regions and widely grown in north, south, west and central parts of the country including, pocket areas in highlands and mid highlands with altitude ranging from 1800-3000 m.a.s.l. 
According to FAO (1998) center of origin/diversity of field pea are East Africa and West Asia with secondary center in South Asia and South and East Mediterranean sub-regions. The species P. sativumis dominant in Ethiopia even though wild and primitive forms are also known to exist in the high elevation of the country (Mussa et al., 2006).

Field pea with other food legumes covers about $11.54 \%$ of the total 1.3 million hectares of crop areas in Ethiopia and is the 3rd most important stable food legume among the highland pulses in rural Ethiopia (CSA, 2012). This crop is very much important in the highlands of Bale, South Eastern Ethiopia since it fetches cash for the farming community and also serves as rotational crop which play great role in controlling disease epidemics in areas were cereal mono cropping is abundant. It also plays a significant role in soil fertility restoration as a suitable rotation crop that fixes atmospheric nitrogen and good source of cash to farmers and foreign currency to the country (Girma, 2003).

Generally, it is a crop of manifold merits in the economic lives of the farming communities of high lands of Ethiopia. It is a rich source of protein $(25 \%)$, carbohydrate $(12 \%)$ s, vitamins $\mathrm{A}$ and $\mathrm{C}$, calcium and phosphorus, apart from having a small quantity of iron. Peas being very rich in proteins are valuable for vegetable purposes. Even though the above facts clearly show the important role the crop plays in the country's agriculture, its average seed yield has remained very low in the highlands of Bale, Ethiopia. (Mo RAD, 2010 )

According to CSA (2011/12), field pea covers about $214,253.07$ ha of the total arable land with a total production of 2,752,981.27 Quintals. This constitutes about $12.85 \%$ of the total area covered by pulses and $12.43 \%$ of the total annual production of pulses in the country. The major reasons are: susceptibility of the landraces to array of diseases, inherently low yield potential of the landraces and poor management practices. Diseases, particularly, Ascochyta blight (Ascochytapisi), Powdery and downy mildew (Erysiphepolygoni) are the major constraints, causing substantial yield loss and instability in yield (ICARDA, 2011). Powdery mildew and Ascochyta blight has been reported to be the major field pea disease in the mid altitudes and may reduce yield by $20-30 \%$ under moderate severity. It also indicated that when the disease is severe, susceptible lines could be killed and in particular, cause severe damage to local landraces in Bale highlands. It is planted in rotation with barley and wheat.

Field pea grows twice a year during "belg" (March to July) and "meher" (July to December). Grain harvest by small farmers falls between 4-6 and 2-3 t/ha in belg and meher seasons respectively around Sinana. Aphids, low yielding a local varieties, lodging, diseases (powdery and downy mildew), and pod shattering are the major production constraints to field pea production in Bale in that order of importance. Dadimos and Tullushenen are new field pea cultivars adapted to the southeastern highlands of Ethiopia, developed by Sinana Agricultural Research Center through its regional breeding program. They are high yielding and medium maturing (140-145 days) with high protein content. Susceptible lines could be killed and in particular, cause severe damage to local landraces in Bale (ICARDA, 2011).

Traditionally, plant breeders have optimized yield largely by empirical selection with little regard for the physiological processes involved in yield increase. More recently, focused on optimize yield in pea have focused on the physiological mechanisms involved in the seed setting and fruit filling However, selection of high yielding cultivars via specific traits requires knowledge of not only final yield but also the many compensation mechanisms among yield components resulting from changing genotypic, environmental and management factors. Grain yield of pea is a quantitative trait which is affected by many genetic and environmental factors (Ranjan et al., 2006).

Genetic variability is an essential prerequisite for crop improvement program for obtaining high yielding varieties. On the other hand, yield is a complex character and is associated with some yield contributing characters. The understanding of association of characters is of prime importance in developing an efficient breeding program. The correlation studies provide information about association between any two characters. The path coefficient analysis provides the partitioning of correlation coefficients into direct and indirect effects giving the relative importance of each of the causal factors (Allard, 1996). Despite the importance of such investigation and much works done to improve the production and productivity of this crop, there isno sufficient work has been done for understanding and describing the nature and extent of GCV, PCV, heritability in broad sense, genetic advance, association between yield and yield related traits of field pea varieties developed for south east high land Ethiopia Therefore, this work has been designed with the following objectives:

The general objective of the present study is

To determine genetic variability, heritability and association among agronomic characters for yield and yield related traits in Pea genotypes at Bale Zone, Ethiopia.

Specific objectives:

1. To estimate the genetic variability of different pea genotypes

2. To estimate heritability and genetic advance of important agronomic characters of pea genotypes.

3. To assess the extent of association among agronomic characters of pea genotype

\section{Materials and Methods}

\subsection{Description of the Study Site}

The study was conducted in Oromia Regional State Bale Zone, Sinana Agricultural Research Center, which is located $475 \mathrm{~km}$ South East of Addis Ababa. The average annual mean temperature of Sinana is $18^{\circ} \mathrm{C}-22^{\circ} \mathrm{C}$. The geographic location of SARC is $07^{\circ} 07^{\prime} \mathrm{N}$ and $40^{\circ} 10^{\prime} \mathrm{E}$ with an elevation of 2400 meters above sea level. The center belongs in the high lands of Bale with average annual rainfall of $823-1567 \mathrm{~mm}$. The dominant soil type is pelvic vertical and slightly acidic $\mathrm{p}^{\mathrm{H}}=6.2$ 
(Teshome, 2011).

\subsection{Experimental Materials}

The materials of the study were 36 pea varieties obtained from IBC and SARC. The seeds of the varieties were sown on $9^{\text {th }}$ August 2013 main growing season.

\subsection{Experimental Design and Trial Management}

The experiment was laid out in Simple Lattice Design (6x6) with two replications of six blocks per replications and six treatments per block as given by Cochran and Cox (1957). Each plot consisted of four rows of $3 \mathrm{~m}$ length with spacing of $20 \mathrm{~cm}$ between rows and $10 \mathrm{~cm}$ between plants. The space between plots within block was $1.5 \mathrm{~m}$ and between blocks within each replication as well as between replications was $1.5 \mathrm{~m}$. Each row was contained 30 plants and each plots contained total of 120 plants. Data were collected from five randomly selected plants of each genotype from each replication for 12 quantitative characters from two central rows. Standard agronomic practices were followed and plant protection measure was taken when required.

\subsection{Data Collected}

The following Characters were recorded on five randomly selected plants from each plot.

1. Plant height $(\mathrm{PH})$ - the height was measured in $\mathrm{cm}$ from the ground level to the top of the Plant.

2. Number of pods per plant (PPP) - the number of healthy pods were taken at Physiological maturity from five randomly selected plants from each Plot and averaged over the sample plant

3. Pod length (PL)- the average length of the pod expressed in $\mathrm{cm}$ at physiological Maturity from five randomly selected plants per plot

4. Seed number per pod (SPP) - the number of seeds were counted per pods of the five And average recorded

5. Days to emergence (DE)- days to emergence was recorded when $50 \%$ of the plant in Each Plot emerged out.

6. Days to flowering (DF)-days to flowering was recorded when $50 \%$ of the plants in each Plot produces flowers.

7. Day to flower initiation (DFI)- day to flower initiation was recorded when the first Flower first opens for each plot.

8. Days to maturity (DM)-was recorded as the day from emergence to maturity when $50 \%$ of the plant population per plot have turned yellowish or showed sign of Senescence

9. Grain Yield per plant (YPP) (g): the grain yield from sample plants was weighed in grams and the averaged

10. 100 seeds weight (TSW) -the weight of 100 seeds were measured from five randomly Selected plants of each plot

11. Above ground Biomass per plot (AGB in $\mathrm{g} / \mathrm{m}^{2}$ ): Above ground biomass on the Plots were harvested, sun dried and weighted to get aboveground biomass.
12. Harvest index (HI): this was calculated by the following formula:

$$
\text { Harvest Index }(H I)=\frac{\text { seed yield per plot }(\mathrm{g}) \times 100}{\text { Biomass per plot }(\mathrm{g})}
$$

\section{Result and Discussions}

\subsection{Analysis of Variance}

The results of analysis of variance of 12 characters for 36 genotypes tested under this study were presented in Table 1. The Analysis of variance indicated that genotypic mean squares were highly significant $(\mathrm{p}<0.01)$ differences for days to flower initiation, days to maturity, plant height, pod length, above ground biomass and 100 seed weight revealed that the presence of adequate variability which can be exploited through selection in breeding of crop for improvement of yield of field pea. This finding is similar to that of (Zakira et al., 2010; Dereje and Tesfaye. 1994). After overall analysis, highly significant $(\mathrm{p}<0.01)$ values were observed for days to flower initiation, days to maturity, plant height, pod length, above ground biomass and 100 seed weight, while seeds per pod and harvest index had significant $(\mathrm{p}<0.05)$ difference among genotypes. This results indicate that the presence of variability among the genotypes that used for effective selection or crop improvement. The results of the study were in agreement with the results reported by (Mulusew et al., 2007).

Table 1. Analysis of variance (mean squares) for the 12 characters of 36 field pea genotypes Growing at Sinana.

\begin{tabular}{llllll}
\hline Traits & $\begin{array}{l}\text { MSg } \\
\text { Df=35 }\end{array}$ & $\begin{array}{l}\text { MSr } \\
\text { Df=1 }\end{array}$ & $\begin{array}{l}\text { MSe } \\
\text { Df=35 }\end{array}$ & CV & $\begin{array}{l}\text { LSD } \\
\mathbf{( 5 \% )}\end{array}$ \\
\hline DE & 1.84 & 48.34 & 1.71 & 15.15 & 2.7 \\
DFI & $26.7 * *$ & 22.2 & 11.02 & 5.63 & 6.7 \\
DF & 23.4 & 5.55 & 15.02 & 5.52 & 7.9 \\
DM & $26.25 * *$ & 1136 & 13.14 & 2.6 & 7.4 \\
PH & $125 * *$ & 2403.6 & 125 & 6.21 & 17.7 \\
PPP & 5.9 & 106 & 5.2 & 11.99 & 4.9 \\
SPP & $0.61 *$ & 0.93 & 0.51 & 12.6 & 1.46 \\
PL & $0.28 * *$ & 1.03 & 0.71 & 8.81 & 0.85 \\
ABG & $1847 * *$ & 4967 & 507 & 19.42 & 14.6 \\
YPP & 20.9 & 274.1 & 9.95 & 18.0 & 6.4 \\
HSW & $3.95 * *$ & 2.53 & 0.89 & 7.0 & 1.92 \\
HI & $87.9 *$ & 449.5 & 25.6 & 15.0 & 17.6 \\
\hline
\end{tabular}

$* *$ and $*$ Significant at $1 \%$ and $5 \%$ probability level respectively

$\mathrm{DF}=$ Days to $50 \%$ flowering $\mathrm{DM}=$ Days to maturity $\mathrm{HI}=$ harvest index $\mathrm{PH}$ $=$ Plant height $(\mathrm{cm}) \mathrm{DE}=$ day to emergency HSW=100 seed weight $(\mathrm{g}) \mathrm{PPP}$ $=$ Number of pod per plant YPP $=$ Yield per plant SPP $=$ Number of seed per pod $\mathrm{PL}=$ Pod length $(\mathrm{cm}) \mathrm{DFI}=$ day to flower initiation $\mathrm{ABG}=$ above ground biomass

\subsection{Phenotypic and Genotypic Variations}

The estimates of environmental, genotypic and phenotypic variances and phenotypic coefficient of variation (PCV) and genotypic coefficient of variation (GCV) are given in Table 2 In the present study, the highest genotypic variance were observed for above ground biomass (1170), days to maturity (63.23), harvest index (31.1) while the lowest genotypic 
variance were found for days to emergence (3.46), seed per pod (2.57), pod length (2.28) and yield per plant (0.74). The highest phenotypic variances were found for above ground biomass (1677), plant height (152.6), days to maturity (76.36) and harvest index (56.7) while days to emergence (5.18) seed per pod (3.11) and pod length (2.45). The highest environmental variances were found for above ground biomass (501), plant height (125) and harvest index (25.6) and the remaining characters were found to have the lowest environmental variation except days to flower initiation (11.02), days to maturity (13.14) and days to flowering (15.02) which had medium environmental variation. The result of (Zakira et al., 2010; Dereje and Tesfaye. 1994) is in agreement with this finding who reported the genetic variability in 49 field pea by analyzing 13 characters.

\subsection{Estimation of Genotypic and Phenotypic Coefficient of Variation}

The range for PCV was 7.5 for day to flower initiation to 62.9 for above ground biomass. The GCV ranged from 2.91 for plant height to 37.9 for above ground biomass. The highest PCV were found for aboveground biomass (62.9), pods length (33.05) and seeds per pod (31.04) while the lowest PCV were observed for plant height (6.85), days to maturity (6.28), days to flower initiation (7.5) and days to flowering (9.28). The highest GCV were found for above ground biomass (37.8) and pod length (31.92). The lowest GCV were observed for days to flower initiation (4.7), days to flowering (7.41), days to maturity (5.69) and plant height (2.91).

The PCV were found to be higher than GCV for all traits (Table 2). This observation was conformity with that of (Pan et al., 2010). Moderate GCV and PCV values were recorded for pod per plant, 100 seed weight and harvest index in \%. These traits having considerable genetic variability offer good opportunity for crop improvement through selection. Similarly (Demisew, 2010) reported that moderate to high PCV and GCV for field pea. PCV and GCV estimates were observed to be high for seeds per pod, pods length, yield per plant, day to emergence and above ground biomass indicating high genetic variability for effective selection. It is in conformity with report of (Teshome, 2011).

The two values differ only slightly indicting lesser influence of the environmental factors. Similar GCV and PCV indicate that the major part of variation is shared by genetic component for the characters studied. High genotypic coefficient of variation indicates availability of high variation. The low value of variation indicates that the selection is not effective for particular character because of the narrow genetic variability (Pandey and Tiwari, 1983)

Table 2. Estimates of phenotypic $\left(\sigma^{2} P\right)$, genotypic $\left(\sigma^{2} g\right)$ and environmental $\left(\sigma^{2} e\right)$ of variances phenotypic (PCV) and genotypic (GCV) coefficient of variability for 12 characters of field pea evaluated at Sinana in 2013.

\begin{tabular}{lllllll}
\hline No. & Characters & $\boldsymbol{\sigma}^{\mathbf{2}} \mathbf{e}$ & $\boldsymbol{\sigma}^{\mathbf{2}} \mathbf{g}$ & $\boldsymbol{\sigma}^{\mathbf{2}} \mathbf{p}$ & $\mathbf{P C V}$ & $\mathbf{G C V}$ \\
\hline 1 & DE & 1.72 & 3.46 & 5.18 & 26.3 & 21.5 \\
2 & DFI & 11.02 & 7.8 & 18.82 & 7.5 & 4.7 \\
3 & DF & 15.09 & 27.65 & 42.74 & 9.28 & 7.47 \\
\hline
\end{tabular}

\begin{tabular}{lllllll}
\hline No. & Characters & $\boldsymbol{\sigma}^{\mathbf{2}}$ & $\boldsymbol{\sigma}^{\mathbf{2}} \mathbf{g}$ & $\boldsymbol{\sigma}^{\mathbf{2}} \mathbf{p}$ & $\mathbf{P C V}$ & $\mathbf{G C V}$ \\
\hline 4 & DM & 13.14 & 63.23 & 76.36 & 6.28 & 5.69 \\
5 & PH & 125. & 27.6 & 152.6 & 6.85 & 2.91 \\
6 & PPP & 5.99 & 7.23 & 13.2 & 17.8 & 13.14 \\
7 & SPP & 0.54 & 2.57 & 3.11 & 31.04 & 28.22 \\
8 & PL & 0.17 & 2.28 & 2.45 & 33.05 & 31.92 \\
9 & ABG & 501 & 1170 & 1677 & 62.6 & 37.9 \\
10 & YPP & 9.95 & 0.74 & 10.64 & 28.6 & 7.52 \\
11 & HSW & 0.89 & 6.49 & 7.38 & 19.58 & 18.36 \\
12 & HI $\%$ & 25.6 & 31.1 & 56.7 & 16.3 & 12.0 \\
\hline
\end{tabular}

$\mathrm{DF}=$ Days to $50 \%$ flowering $\mathrm{DM}=$ Days to maturity $\mathrm{HI}=$ harvest index $\mathrm{PH}$ $=$ Plant height $(\mathrm{cm})$

$\mathrm{DE}=$ day to emergency HSW $=100$ seed weight $(\mathrm{g}) \mathrm{PPP}=$ Number of pod per plant

YPP $=$ Yield per plant SPP $=$ Number of seed per pod $\mathrm{PL}=$ Pod length $(\mathrm{cm})$ $\mathrm{DFI}=$ day to flower initiation $\mathrm{ABG}=$ above ground biomass

Table 3. Estimates of broad sense heritability $\left(H^{2}\right)$, expected genetic advance (GA) and genetic advance as percent of mean (GA \%) for 12 characters of field pea evaluated at Sinana in 2013.

\begin{tabular}{lllll}
\hline No & Characters & $\mathbf{H}^{2}$ & GA & GA M\% \\
\hline 1 & DE & 66.8 & 3.13 & 36.2 \\
2 & DFI & 41.4 & 3.69 & 6.27 \\
3 & DF & 64.7 & 8.72 & 12.37 \\
4 & DM & 82.8 & 14.9 & 10.67 \\
5 & PH & 18.08 & 4.6 & 2.55 \\
6 & PPP & 54.7 & 4.09 & 20.02 \\
7 & SPP & 82.6 & 2.99 & 52.65 \\
8 & PL & 93.0 & 2.99 & 63.36 \\
9 & ABG & 69.76 & 58.84 & 2.15 \\
10 & YPP & 6.9 & 0.46 & 4.08 \\
11 & HSW & 87.9 & 4.9 & 35.39 \\
12 & HI\% & 54.8 & 7.71 & 18.51 \\
\hline
\end{tabular}

$\mathrm{DF}=$ Days to $50 \%$ flowering $\mathrm{DM}=$ Days to maturity $\mathrm{HI}=$ harvest index $\mathrm{PH}=$ Plant height $(\mathrm{cm}) \mathrm{DE}=$ day to emergency HSW $=100$ seed weight $(\mathrm{g})$ PPP $=$ Number of pod per plant YPP $=$ Yield per plant SPP $=$ Number of seed per pod

$\mathrm{PL}=$ Pod length $(\mathrm{cm}) \mathrm{DFI}=$ day to flower initiation $\mathrm{ABG}=$ above ground biomass

\subsection{Estimates of Heritability $\left(\mathrm{H}^{2}\right)$ in Broad Sense}

In the present work, heritability estimate for 12 characters studied indicated that the high heritability were found for day to emergence (66.8), day to flowering (64.7), day to maturity (82.8), seeds per pod (82.6), pod length (93.0), above ground biomass (69.76) and 100 seed weight (87.9). The lowest heritability were observed for yield per plant (6.9) and plant height (18.08). While the remaining had moderate heritability. Moderate heritability estimate were found for harvest index in $\%$, pod per plant and day to flower initiation, such moderate value indicted the limit scope for crop improvement of this characters. This result was in agreement with the report of (Vander Maesen et al., 2011) who have show in field pea have high broad sense heritability in pod length and days to maturity.

Singh (1990) observed that if the heritability of characters is very high (around $80 \%$ and above) selection for such characters should easy. This is because there would be close correspondence between the genotype and environmental to the phenotype. Most the characters studied show very high 
heritability estimates indicating the possibility of improving these traits through selection. This result was similar with the finding of (Zakira et al., 2010).

\subsection{Estimates of Expected Genetic Advance (GA)}

Genetic advance measures the expected genetic progress that would result from selecting the best performing genotypes for a character being evaluated (Allard, 1999). The estimates of heritability and genetic advance should be considered simultaneously as high heritability is not always associated with high genetic gain. The expected genetic advance expressed as percentage of mean by selecting the top $5 \%$ (higher yielder) of the genotypes. The range of genetic advance as percent of mean varied from 2.15 for above ground biomass to 63.36 for pod length (Table 3). The highest GAM were found for pod length (63.36), seed per pod (52.65), days to emergence (36.2) and 100 seed weight (35.39).

The lowest GAM were observed for days to flower initiation (6.27), yield per plant (4.08), plant height (2.55) and above ground biomass (2.15). This indicates that selecting the top $5 \%$ of the base population could result in an advance over the population mean. Comparatively, high genetic advance as percentage of mean were observed for day to emergence, pod per plant, seed per pod, pod length and 100 seed weight. Hence, selection for such characters is likely to be effective as high heritability values were associated with high genetic advance. In agreement with this study (Teshome, 2011) reported that high heritability and genetic advance as percentage of mean was observed in day to emergence, seed per pod, 100 seed weight and pod length.

Value of genetic advance was recorded for yield per plant, above ground biomass, plant height and day to flower and day to flower initiation were low. Similarly (Zakira et al., 2010) reported that the low genetic advance for above characters revealed that selection of accessions based on phenotypic performance for those with low genetic advance would not be effective. There for, high heritability associated with high genetic advance implied that improving these traits could be possible via selection because of high heritability with high genetic advance effective. There for high heritability associated with high genetic advance implied that improving these traits could be possible via selection because of high heritability with high genetic advance.

\subsection{Association Among Yield and Yield Components}

Correlation studies provide information on the nature and extent of association between any two pairs of metric characters. From this, it would be possible to bring about genetic up gradation in one character by selection of the other of pair. Grafius (1964) opined that there might not be any gene for yield as such, but operates only through its components.

An attempt has been made to study the character association in the field pea varieties, both at phenotypic and genotypic level. In general, the genotypic correlation coefficient values were higher than the phenotypic values. This indicates the strong intrinsic associations are somewhat marked at phenotypic level due to environmental effect. The higher genotypic values whenever observed are contributed to the relative stability of the genotypes (Togay et al., 2008)

The results of phenotypic and genotypic correlation between yield and their components in the present investigation are discussed below. The data presented in table 6 and 7 revealed that genotypic correlation coefficient were slightly lower in magnitude than phenotypic ones. This low magnitude is due to modifying effects of environment on the association characters. There was a general agreement in both sign and magnitude between estimates of genotypic and phenotypic correlations. The characters, which are genotypic ally but not phenotypic ally correlated may not be of practical value in selection since selection is based on phenotype (Singh, 1990)

\subsubsection{Estimates of Genotypic Correlation Coefficient of Seed Yield with Other Components}

The seed yield per plant recorded highly significant and positive genotypic correlation with days to emergence $\left(\mathrm{rg}=0.296^{* *}\right)$, days to maturity $(\mathrm{rg}=0.184 * *)$, number of seeds per pod $\left(\mathrm{rg}=0.325^{* *}\right)$ and harvest index in $\%\left(\mathrm{rg}=0.341^{* *}\right)$. Day to flowering $\left(\mathrm{rg}=0.143^{*}\right)$ and pod length $\left(\mathrm{rg}=0.331^{*}\right)$ had significant and positive genotypic correlation with yield per plant A significant and negative correlation of seed yield was observed with day to flower initiation $(\mathrm{rg}=-0.704 *)$ whereas, number of pod per plant ( $\mathrm{rg}=0.154)$, plant height $(\mathrm{rg}=0.151)$, day to $50 \%$ flowering ( $\mathrm{rg}=0.143$ ), above ground biomass and 100 seed weight recorded positive but non-significant correlation with this trait. Generally, in those characters in which seed yield showed positive and significant correlation, there were components interactions in which a gene conditioning an increase in one characters will influence another provided other conditions are kept constant. Similar result was reported by (Zakira et al., 2010 and Srikamis et al., 2010).

\subsubsection{Estimates of Genotypic Correlation Coefficient Among the Others}

Days to emergence showed a highly significant and positive correlation with days to maturity $\left(\mathrm{rg}=0.687^{* *}\right)$, whereas above ground biomass $\left(\mathrm{rg}=-0.865^{* *}\right)$ and harvest index $\left(\mathrm{rg}=-0.616^{* *}\right)$ had highly significant and negative genotypic correlation with yield per plant. It implies that plant that early emerge may mature earlier and increase seed yield in field pea, which have positive and significant correlation with crop improvement. Similar result was reported by (Kebere et al., 2006).

It also recorded significant and negative correlation with day to $50 \%$ flowering $\left(\mathrm{rg}=-0.85^{*}\right)$, day to flower initiation $\left(\mathrm{rg}=-0.168^{*}\right)$ and pod length $\left(\mathrm{rg}=-0.195^{*}\right)$ whereas, number of seeds per pod, plant height $(\mathrm{rg}=0.006)$ and 100 seed weight recorded positive but non-significant correlation with this trait. Days to flower initiation showed a highly significant and positive correlation with 100 seed weight $(\mathrm{rg}=0.62 * *)$ and yield per plant $(\mathrm{rg}=0.71 * *)$. 
Table 4. Genotypic correlation coefficients between different yield componentsin field pea.

\begin{tabular}{|c|c|c|c|c|c|c|c|c|c|c|c|c|}
\hline & DE & DFI & DF & DM & PH & PPP & SPP & PL & HI\% & AGB & HSW & YPP \\
\hline $\mathrm{DE}$ & 1 & $-0.168 *$ & -0.85 & $0.687 * *$ & 0.006 & 0.027 & 0.047 & $-0.195 *$ & $-0.616^{* *}$ & $-0.865^{* *}$ & -0.008 & $0.296^{* *}$ \\
\hline DFI & & 1 & 0.064 & 0.172 & 0.015 & 0.053 & -0.032 & -0.031 & 0.103 & -0.034 & $0.62 * *$ & $-0.704 *$ \\
\hline DF & & & 1 & 0.005 & 0.016 & 0.023 & 0.028 & -0.032 & 0.059 & 0.041 & -0.008 & $0.143^{*}$ \\
\hline DM & & & & 1 & 0.009 & 0.019 & 0.009 & -0.014 & 0.032 & 0.034 & -0.009 & $0.184^{* *}$ \\
\hline PH & & & & & 1 & 0.085 & -0.059 & -0.059 & 0.095 & $0.146^{*}$ & -0.033 & 0.151 \\
\hline PPP & & & & & & 1 & 0.085 & -0.059 & 0.095 & 0.146 & -0.334 & 0.154 \\
\hline SPP & & & & & & & 1 & 0.059 & 0.102 & 0.182 & -0.198 & $0.325^{* *}$ \\
\hline PL & & & & & & & & 1 & 0.125 & $-0.513^{*}$ & -0.036 & $0.331^{*}$ \\
\hline HI\% & & & & & & & & & 1 & 0.013 & 0.0038 & $0.341^{* *}$ \\
\hline AGB & & & & & & & & & & 1 & -0.118 & 0.056 \\
\hline HSW & & & & & & & & & & & 1 & 0.048 \\
\hline YPP & & & & & & & & & & & & 1 \\
\hline
\end{tabular}

*and** significant at 0.05 and 0.01 respectively

$\mathrm{DE}=$ day to emergence $\mathrm{PH}=$ plant height $\mathrm{YPP}=$ yield per plant $\mathrm{DFI}=$ day to flower initiation $\mathrm{PPP}=$ pod per plant,

$\mathrm{AGB}=$ aboveground biomass $\mathrm{DF}=$ day to flowering $\mathrm{SPP}=$ seed per pod $\mathrm{HSW}=100$ seeds weight

$\mathrm{DM}=$ day to maturity $\mathrm{PL}=$ pod length $\mathrm{HI} \%=$ Harvest index in $\%$

Days to maturity ( $\mathrm{rg}=0.172)$, day to emergence $(\mathrm{rg}=0.168)$, number of pod per plant $(\mathrm{rg}=0.053)$ also recorded non significant and positive correlation whereas, above ground biomass per plot $\left(\mathrm{rg}=-0.035^{*}\right)$, pod length $\left(\mathrm{rg}=-0.031^{*}\right)$ and harvest index in\% $(\mathrm{rg}=-0.103 *)$, plant height recorded negative but significant correlation with this trait. This indicates that genotypes that flower early may mature early and produce more seed that have positive and significant correlation with crop improvement which conformity by result of (Teshome, 2011).

Plant height showed a significant and positive correlation with above ground biomass per plot $\left(\mathrm{rg}=0.146^{*}\right)$. Whereas, the remaining traits are not significant. Above ground biomass recorded negative and significant correlation with pod length $(\mathrm{rg}=-0.513 *)$. Whereas the remaining characters expressed positively but non-significant association with this trait. This implies that as the size of pod reduced, the number of seed it contain may decreased, which result in low yield that indirectly affect overall biomass of plant. Similar result was found by (Mussa et al., 2006).

Number of pod per plant have positive and highly significant correlation was recorded with day to emergence $\left(\mathrm{rg}=0.331^{* *}\right)$, days to $50 \%$ flowering $\left(\mathrm{rg}=0.738^{* *}\right)$, days to maturity $\left(\mathrm{rg}=0.552^{* *}\right)$, plant height $\left(\mathrm{rg}=0.921^{* *}\right)$, pod length $\left(\mathrm{rg}=0.698^{* *}\right)$, number of seed per plant $\left(\mathrm{rg}=0.914^{* *}\right)$ and 100 seed weight $\left(\mathrm{rg}=0.713^{* *}\right)$. This trait showed a negative, significant correlation with harvest index in\% $\left(\mathrm{rg}=-0.627^{*}\right)$ and above ground biomass $(\mathrm{rg}=-0.433 *)$. This result indicates that the number of pod bear on plant my increase the biomass of plant which have impact on crop improvement in field pea. This conformity with result reported by (Tesfaye, 1999).

100 seed weight exhibited positive and significant correlation with pod length $\left(\mathrm{rg}=0.713^{* *}\right)$ number of seed per plant $\left(\mathrm{rg}=0.445^{* *}\right)$ and plant height $\left(\mathrm{rg}=0.577^{* *}\right)$ whereas, yield per plant $\left(\mathrm{rg}=-0.943^{*}\right)$ and day to maturity $\left(\mathrm{rg}=-0.638^{*}\right)$ recorded negatively significant correlation and remaining characters showed positive non-significant correlation with this trait indicating that fewer but heavier seeds per pod in the large field pea types contribute to the higher production of yield per plant. Similar result was reported by (Teshome, 2011).

Above ground biomass exhibited positive and significant correlation with plant height $\left(\mathrm{rg}=0.823^{* *}\right)$, number of seed per pod $\left(\mathrm{rg}=0.423^{* *}\right)$ and yield per plant $\left(\mathrm{rg}=0.664^{* *}\right)$ whereas, number of pod per plant $\left(\mathrm{rg}=-0.631^{*}\right)$ recorded negatively significant correlation but the remaining characters showed non-significant correlation with this trait This implies that the delay in flowering result in low biomass which have impact on crop improvement. Similar result was reported by (Zakira $e t$ al., 2010).

Harvest index in\% exhibited positive and significant correlation with plant height $\left(\mathrm{rg}=0.621^{* *}\right)$ and pod length $\left(\mathrm{rg}=0.712^{* *}\right)$ whereas, number of pod per plant $\left(\mathrm{rg}=-0.421^{*}\right)$, number of seed per pod $(\mathrm{rg}=-0.512 *)$ recorded negatively significant correlation whereas, the remaining characters showed non-significant correlation with this trait This implies that the two characters have positive impact on crop improvement. Similar result was reported by (Milion, 2012).

\subsubsection{Estimates of Phenotypic Correlation of Seed Yield with Other Components}

The seed yield per plant recorded highly significant and positive phenotypic correlation with days to 50 per cent flowering $\left(\mathrm{rp}=0.836^{* *}\right)$, pod length $\left(\mathrm{rp}=0.676^{* *}\right)$, day to emergence $\left(\mathrm{rp}=0.192^{* *}\right)$ and seed per pod $\left(\mathrm{rp}=0.695^{* *}\right) .100$ seed weight $(\mathrm{rp}=0.512 *)$, harvest index in $\%(\mathrm{rp}=0.249 *)$ and number of pods per plant $\left(\mathrm{rp}=0.357^{*}\right)$ had significant and positive correlation with yield per plant. This revealed that, improvement in any one or all of these positively related traits had contributed to selection of these characters for seed yield improvement progress similar finding was reported by Jacobs (2010) in field pea.

\subsubsection{Estimates of Genotypic Correlation Coefficient Among the Others}

Day to emergence recorded a highly significant and positive correlation with pod per plant $\left(\mathrm{rp}=0.931^{* *}\right)$. Plant height $\left(\mathrm{rp}=0.258^{*}\right)$, day to maturity $\left(\mathrm{rp}=0.512^{*}\right)$, number of seed per pod $\left(\mathrm{rp}=0.463^{*}\right)$ whereas the remaining traits were not significant. This result indicates that change in any one of these characters in either direction might have significant impact on the field pea seed yield improvement. Similarly Demisew (2010) reported high significant and positive 
correlation with above characters. Day to flower initiation showed highly significant and positive phenotypic correlation with pod per plant $\left(\mathrm{rp}=7138^{* *}\right)$. seed per pod $(\mathrm{rp}=0.852 * *)$ and day to maturity $\left(\mathrm{rp}=0.246^{* *}\right)$.

Table 5. Phenotypic correlation coefficients between different yield components in field pea.

\begin{tabular}{|c|c|c|c|c|c|c|c|c|c|c|c|c|}
\hline & DE & DFI & DF & DM & PH & PPP & SPP & PL & HI\% & AGM & HSW & YPP \\
\hline $\mathrm{DE}$ & 1 & -0.541 & -0.261 & $0.512 *$ & $0.258 *$ & $0.931 * *$ & $0.463^{*}$ & -0.221 & 0.084 & 0.131 & 0.129 & $0.192 * *$ \\
\hline DFI & & 1 & 0.157 & $0.246^{* *}$ & 0.164 & $0.713 * *$ & $0.852 * *$ & 0.171 & $0.269^{*}$ & 0.059 & -0.034 & 0.125 \\
\hline DF & & & 1 & 0.195 & $0.461 *$ & $0.241 *$ & $0.455^{*}$ & -0.474 & 0.153 & -0.229 & -0.205 & $0.836 * *$ \\
\hline DM & & & & 1 & 0.178 & $0.336 * *$ & $0.378^{*}$ & -0.236 & 0.112 & $0.247 *$ & 0.149 & 0.071 \\
\hline PH & & & & & 1 & 0.192 & 0.012 & -0.321 & $0.61 * *$ & 0.144 & -0.192 & $0.131 *$ \\
\hline PPP & & & & & & 1 & 0.122 & $0.388 *$ & 0.028 & 0.023 & -0.047 & $0.357 *$ \\
\hline SPP & & & & & & & 1 & $0.203 *$ & 0.091 & 0.136 & -0.265 & $0.695 * *$ \\
\hline $\mathrm{HI} \%$ & & & & & & & & & 1 & 0.086 & 0.066 & $0.249 *$ \\
\hline AGM & & & & & & & & & & 1 & -0.108 & 0.094 \\
\hline HSW & & & & & & & & & & & 1 & $0.512 *$ \\
\hline YPP & & & & & & & & & & & & 11111111 \\
\hline
\end{tabular}

*and $* *$ significant at $5 \%$ and $1 \%$ respectively $\mathrm{DE}=$ day to emergence $\mathrm{PH}=$ plant height $\mathrm{YPP}=$ yield per plant $\mathrm{DFI}=$ day to flower initiation $\mathrm{PPP}=$ pod per plant $\mathrm{ABM}=$ aboveground biomass $\mathrm{DF}=$ day to flowering $\mathrm{SPP}=$ seed per pod $\mathrm{HSW}=100$ seeds weight $\mathrm{DM}=$ day to maturity $\mathrm{PL}=$ pod length $\mathrm{HI} \%=\mathrm{Harvest}$ Index

Harvest index in $\%\left(\mathrm{rp}=0.265^{*}\right)$ had recorded positive and significant correlation whereas, the remaining characters expressed positive non-significant association with this character. These result was in agreement with report of (Kebere et al., 2008). It recorded a highly significant and positive correlation with days to maturity $(\mathrm{rp}=0.412 * *)$, days to emergence $(0.502 * *)$, number of seeds per pod $(\mathrm{rp}=0.859 * *)$ and number of pods per plant $\left(\mathrm{rp}=0.719^{* *}\right)$ which indicates that days of flower initiation have relationship with seed yield per plant This result indicates that the late flowering and maturity plant my produce few and short pods which have significant and negative impact on field pea seed yield improvement. Similarly result was reported by (Mulusew et al., 2009). A positive, significant correlation was recorded with day to emergence, plant height, harvest index in \%, number of pods per plant and number of seeds per pod. This result may be the indication of vigorous plants having much productivity as compared with the others. This result contradict with the ideotype of field pea hypothesized by Ambrose and Hedley (1984) who suggested that a preferred field pea ideotype

\subsection{Path Coefficient Analysis}

The yield is dependent on several component characters that are mutually associated which will in turn impair the true association existing between a component and economic characters and change in any one component is likely to disturb the whole network of cause and effect. Each component has two parts of action i.e (1) the direct effect and (2) indirect effects through components on economic characters which are not revealed from the correlation studies. Path analysis first suggested by (Wright 1921).

In the present study, 12 characters were considered for path analysis (Table 6). The characters like plant height $(0.419)$, day to maturity (0.189), day to flower initiation (0.066) and number of seed per pod (0.087) has positively direct effect on seed yield while day to $50 \%$ flowering, day to emergence, yield per plant, number of pod per plant and harvest index in \% has negative direct effect for genotypic path. Similar result was found by Girma (2004). It suggested that maximum emphasis should be given on day to maturity, plant height, day to flowering, day to flower initiation and seed per pod were the most important yield contributing characters. Therefore selection based on these traits would give better response for the improvement of yield in pea.

Table 6. Direct (diagonal) and indirect effect of different traits on seed yield per plant at genotypic level.

\begin{tabular}{|c|c|c|c|c|c|c|c|c|c|c|c|c|}
\hline & DE & DFI & DF & DM & PH & PPP & SPP & PL & HI & ABM & HSW & rg \\
\hline DE & -0.484 & 0.005 & -0.056 & -0.740 & 0.003 & -0.008 & 0.004 & 0.037 & 0.069 & 0.035 & 0.002 & 0.296 \\
\hline DFI & 0.006 & -0.035 & 0.004 & 0.033 & 0.006 & -0.002 & -0.003 & 0.006 & -0.011 & -0.884 & -0.001 & -0.704 \\
\hline DF & -0.056 & 0.004 & 0.066 & 0.001 & 0.007 & -0.007 & 0.002 & 0.006 & -0.007 & 0.343 & -0.216 & 0.143 \\
\hline DM & -0.130 & 0.033 & 0.004 & 0.189 & 0.004 & -0.006 & 0.008 & 0.003 & -0.004 & 0.884 & 0.019 & 0.184 \\
\hline PH & 0.003 & 0.006 & 0.001 & 0.002 & 0.419 & -0.003 & -0.005 & 0.011 & -0.011 & -0.006 & 0.069 & 0.151 \\
\hline PPP & -0.001 & -0.002 & 0.002 & 0.004 & 0.036 & -0.030 & 0.007 & 0.011 & -0.011 & 0.068 & 0.070 & 0.154 \\
\hline SPP & 0.004 & -0.003 & 0.002 & 0.002 & -0.025 & -0.003 & 0.087 & -0.011 & -0.011 & -0.007 & 0.042 & 0.325 \\
\hline PL & 0.037 & 0.006 & -0.002 & -0.003 & -0.025 & 0.002 & 0.005 & -0.188 & -0.014 & 0.021 & 0.008 & 0.331 \\
\hline HI & 0.069 & -0.011 & 0.004 & 0.006 & 0.040 & -0.003 & 0.009 & -0.024 & -0.111 & -0.005 & -0.008 & 0.341 \\
\hline $\mathrm{ABM}$ & 0.035 & 0.001 & 0.003 & 0.006 & 0.061 & -0.004 & 0.016 & 0.097 & -0.001 & -0.040 & 0.002 & 0.056 \\
\hline HSW & 0.002 & -0.001 & -0.005 & -0.002 & -0.014 & 0.010 & -0.017 & 0.007 & -0.004 & 0.005 & -0.002 & 0.048 \\
\hline
\end{tabular}

$\mathrm{DE}=$ day to emergence $\mathrm{PH}=$ plant height $\mathrm{YPP}=$ yield per plant $\mathrm{DFI}=$ day to flower initiation $\mathrm{PPP}=$ pod per plant $\mathrm{ABM}=$ aboveground biomass $\mathrm{DF}=$ day to flowering $\mathrm{SPP}=$ seed per pod $\mathrm{HSW}=100$ seeds weight $\mathrm{DM}=$ day to maturity $\mathrm{PL}=$ pod length $\mathrm{HI} \%=$ Harvest index in $\%$ 
The path analysis (Table 6.) for seed yield per plant was performed with a set of 11 independent characters viz., day to emergence, day to flower initiation days to 50 per cent flowering, days to maturity, plant height, above ground biomass, pod length, number of pods per plant, number of seeds per pod, 100 seed weight and Harvest index in\%. Days to emergence had high negative direct effect on seed yield (-0.484). The highest positive correlation of day to emergence with yield per plant $\left(\mathrm{rg}=292^{* *}\right)$ arose due to the maximum indirect effect of day to emergence through other characters and its direct negative effect on yield per plant. Indirect negative effect was observed through days to maturity $(-0.74)$, day to flowering $(-0.056)$ and number of pods per plant $(-0.008)$. Indirect positive effect was observed through plant height (0.003), above ground biomass (0.035), day to emergence $(0.005)$, pod length $(0.037), 100$ seed weight $(0.002)$, number of seeds per pod (0.004) and harvest index in \% (0.069). Similar result was reported by (Keneni et al., 2005).

Day to maturity had high positive, direct effect on yield (0.189). Positive indirect effect was observed through plant height (0.004), day to flower initiation (0.33) seed per pod $(0.008)$, pod length $(0.003), 100$ seed weight $(0.019)$ and above ground biomass $(0.884)$. Negative, indirect effect was shown by days to emergence $(-0.130)$, harvest index $\%(-0.004)$ and pod per pod $(-0.006)$ The positive correlation of day to maturity $\left(\mathrm{rg}=0.84^{*}\right)$ with yield per plant came from the positive direct effect of day to maturity and small negative indirect effect through pod per plant, day to emergence, harvest index \%. This finding was conformity with that of (Manender et al., 2012).

Plant height showed high positive, direct effect on yield (0.419). Indirect, positive effect was shown by days to 50 per cent flowering (0.001), days to maturity $(0.002)$, day to emergence $(0.003)$ day to flower initiation $(0.006), 100$ seed weight $(0.033)$ and pod length $(0.011)$. Indirect, negative effects were shown by plant height $(-0.34)$, above ground biomass $(-0.006)$, pod per plant $(-0.003)$, number of seeds per pod $(-0.005)$, and harvest index in \% $(-0.011)$. The positive correlation of plant height with yield per plant $(\mathrm{rg}=0.151)$ came from the positive direct effect of plant height and small negative indirect effect through pod per plant, seed per pod, harvest index in\% and above ground biomass. This result was similar with that of (Nawab et al., 2009) reported on field pea.

Pod length showed a negative, direct effect on yield $(-0.188)$. Indirect, negative effect of pod length on seed yield was seen via to plant height $(-0.025)$, day to maturity $(-0.003)$, day to flowering $(-0.002)$ and harvest index in\% $(-0.014)$. Indirect, positive effect was shown by pod per plant $(0.002)$, day to emergence $(0.037)$, day to flower initiation $(0.006)$, above ground biomass (0.021), number of seeds per pod (0.005) and 100 seed weight (0.008). The positive correlation of pod length with yield per plant $\left(\mathrm{rg}=331^{* *}\right)$ arose due to maximum indirect effect of pod length through other traits and its direct negative effect on grain yield. Similar result was reported by (Asnake, 2004).

Harvest index in\% had low negative direct effect on seed yield $(-0.111)$. Indirect positive effect was observed by number of seeds per pod (0.009), day to emergence $(0.069)$, day to flowering (0.004), day to maturity (0.006) and plant height (0.040). However, indirect negative effects were shown by days to flower initiation $(-0.011)$, pods per plant $(-0.003)$, pod length (-0.024), above ground biomass $(-0.005)$ and 100 seed weight $(-0.008)$. The positive correlation of harvest index in $\%$ with yield per plant $\left(\mathrm{rg}=0.341^{* *}\right)$ counter balanced through other indirect effect of harvest index in $\%$ and its negative direct effect on seed yield. Similar result was reported by (Ceyan et al., 2012).

The path coefficient analysis at the phenotypic level based on the seed yield as dependent variable (Table 7) showed that days to flowering (2.056), plant height (0.757), seeds per pod (0.939), pod length (2.211), above ground biomass (1.005) and 100 seed weight (1.754) revealed positive direct effect on seed yield. Their indirect effects via other characters were mostly positive and negligible. Therefore, their positive correlation coefficient with seed yield was mainly due to their direct effect. However, days to emergence $(-0.088)$, days to flower initiation $(-1.214)$, day to maturity $(-0.357)$, pod per plant $(-0.113)$ and harvest index (-0.617) had negative direct effect on seeds yield per plant. Their indirect effect via other characters were negligible therefore, their positive correlation coefficient with seed yield was mainly due to their direct effect. This finding is similar with that of (Ali et al., 2009).

Table 7. Direct and indirect effects of different traits on seed yield per plant at Phenotypic level.

\begin{tabular}{|c|c|c|c|c|c|c|c|c|c|c|c|}
\hline & DE & DFI & DF & DM & PH & PPP & SPP & PL & HI & ABM & HSW \\
\hline $\mathrm{DE}$ & -0.088 & 0.657 & -0.537 & -0.183 & 0.195 & -0.105 & 0.435 & -0.489 & -0.052 & 0.132 & 0.226 \\
\hline DFI & 0.048 & -1.214 & 0.323 & -0.088 & 0.124 & -0.080 & 0.800 & 0.378 & -0.166 & 0.059 & -0.060 \\
\hline DF & 0.023 & -0.191 & 2.056 & -0.070 & 0.349 & -0.027 & 0.427 & -1.048 & -0.094 & -0.230 & -0.359 \\
\hline DM & -0.045 & -0.299 & 0.401 & -0.357 & 0.135 & -0.038 & 0.355 & -0.522 & -0.069 & 0.248 & 0.261 \\
\hline PH & -0.023 & -0.199 & 0.948 & -0.064 & 0.757 & -0.022 & 0.011 & -0.710 & -0.376 & 0.145 & -0.337 \\
\hline PPP & -0.082 & -0.865 & 0.495 & -0.120 & 0.145 & -0.113 & 0.115 & 0.858 & -0.017 & 0.023 & -0.082 \\
\hline SPP & -0.041 & -1.034 & 0.935 & -0.135 & 0.009 & -0.014 & 0.939 & 0.449 & -0.056 & 0.106 & -0.465 \\
\hline PL & 0.019 & -0.208 & -0.974 & 0.084 & -0.243 & -0.044 & 0.191 & 2.211 & -0.050 & -0.105 & -0.205 \\
\hline HI & -0.007 & -0.326 & 0.315 & -0.040 & 0.462 & -0.003 & 0.085 & 0.179 & -0.617 & 0.086 & 0.116 \\
\hline $\mathrm{ABM}$ & -0.012 & -0.072 & -0.471 & -0.088 & 0.109 & -0.003 & 0.100 & -0.232 & -0.053 & 1.005 & -0.189 \\
\hline HSW & -0.011 & 0.041 & -0.421 & -0.053 & -0.145 & 0.005 & -0.249 & -0.259 & -0.041 & -0.109 & 1.754 \\
\hline
\end{tabular}

$\mathrm{DE}=$ day to emergence $\mathrm{PH}=$ plant height $\mathrm{YPP}=$ yield per plant $\mathrm{DFI}=$ day to flower initiation $\mathrm{PPP}=$ pod per plant $\mathrm{ABM}=$ aboveground biomass $\mathrm{DF}=$ day to flowering $\mathrm{SPP}=$ seed per pod $\mathrm{HSW}=100$ seeds weight $\mathrm{DM}=$ day to maturity $\mathrm{PL}=$ pod length $\mathrm{HI} \%=$ Harvest index in $\%$ 
Days to flowering that had positive and highly significant correlation coefficient $\left(\mathrm{rp}=0.836^{* *}\right)$ with seed yield had the highest negative direct effect (-1.214). This implies that days to flowering affect seed yield improvement indirectly. 100 seed weight had positive significant correlation coefficient $\left(\mathrm{r} p=0.512^{*}\right)$ with seed yield had the highest positive direct effect (1.754). This result indicated that the correlation explains true relationships and direct selection through this traits will be effective. The highest positive direct effect of pod length, seed per pod, above ground biomass, plant height, with positive significant phenotypic correlation coefficient with seed yield per plant influence seed yield directly through other characters (Temene, 1998). Therefore, from the result of this study high consideration should be given to days to flowering, pod length, 100 seed weight, seeds per pod, above ground biomass and plant height to improve field pea yield, since they showed positive direct effect with seeds yield per plant.

\section{Summary, Conclusions and Recommendations}

\subsection{Summary and Conclusions}

The ultimate goal of plant breeding programmers' is to improve the plant traits for agronomic and economic superiority Improvement in productivity of any crop depends on the availability of variable material or germplasm for utilizing it in breeding programmer and successful determination of breeding value of it. Phenotypic variance measures the magnitude of variation arising out of differences in phenotypic values while the genotypic variance measures the magnitude of variation due to differences in genotypic value.

The experiment comprised of thirty six genotypes of field pea (Pisumsativum L.) collected from different locations in Ethiopia were evaluated in a simple lattice design with two replications during 2013 at Sinana Agricultural Research Center, Bale for 12 characters to evaluate the genetic variability, associations, direct and indirect effects of yield contributing components on seed yield.

Analysis of variances ANOVA for each characters showed the genotypes were highly significantly difference at $(p<0.01)$ for all characters except day to emergence, pod length, seed per pod and 100 seed weight characters studied indicating the existence of variability among the tested traits.

Genotypic and phenotypic coefficients of variation were high for plant height, pod length harvest index in $\%$ and above ground biomass per plot, number of pods per plant and seed yield per plant indicating that greater influence of environment on genetic variation.

Heritability ranged from 6.9 for yield per plant to 93.0 for pod length (Table 3 ). High heritability estimates were obtained for day to emergence, day to flowering, day to maturity, seed per pod, pod length, above ground biomass and 100sw. The characters like plant height, pod length,, number of pods per plant and seed yield per plant exhibited high heritability coupled with a high genetic advance indicating that simple selection Scheme would be sufficient for these traits to bring genetic improvement in desired direction.

The expected genetic advance expressed as percentage of mean by selecting the top 5\% (higher yielder) of the genotypes varied from 2.15 for above ground biomass to 63.36 for pod length (Table 3). This indicates that selecting the top $5 \%$ of the base population could result in an advance over the population mean. Comparatively, high expected genetic advance as percentage of mean were observed for day to emergence, pod per plant, seed per pod, pod length and 100 seed weight. Hence, selection for such characters is likely to be effective as high heritability values were associated with high genetic advance.

At both phenotypic and genotypic level, seed yield showed positive and significant association with all characters except above ground biomass, number of seeds per pod, 100 seed weight. Harvest index in $\%$ showed significant negative correlation with seed yield.

Strong association of days to 50 per cent flowering, days to maturity, plant height, pod length, day to emergence and number of pods per plant with seed yield per plant revealed that selection based on these traits would ultimately improve the yield and it also suggested that hybridization of genotypes possessing different combinations of such characters is most useful for obtaining desirable high yielding varieties.

Path coefficient analysis at genotypic level revealed that plant height had highest significant positive direct effect on seed yield (0.412) followed by day to maturity whereas day to emergence had negative direct genotypic path analysis (0.189). Hence, it would be rewarding to lay stress on these characters in selection program for increasing yield.

The path coefficient analysis at the phenotypic level based on the seed yield showed that days to flowering, plant height, seeds per pod, pod length, above ground biomass and 100 seed weight revealed positive direct effect on seed yield indicated that direct selection of those characters can improve seed yield in field pea.

The present study revealed that the presence of significant genetic variability among the studied genotypes. Also showed that the existence of significantly positive correlation between seed yield and others yield components, indicating that selection for any one of them permits improvement in seed yield. An attempt has been made to study the character association in the field pea varieties, both at phenotypic and genotypic level.

In general, the genotypic correlation coefficient values were higher than the phenotypic values. It conclude that the strong intrinsic associations are somewhat marked at phenotypic level due to environmental effect. The higher genotypic values whenever observed are contributed to the relative stability of the genotypes. These traits could be used as selection criteria to improve field Pea seed yield. Genotype Ps-237060 and Ps-239313 were found to be superior in terms of grain yield as well as in other important yield components. It is, therefore, suggested that these accessions could be used for further improvement of the field pea crop for improved grain yield. 


\subsection{Recommendation}

1. Sufficient work should be done for understanding and describing the nature and extent of GCV, PCV, heritability in broad sense, genetic advance, association between yield and yield related traits of field pea varieties developed for south east high land Ethiopia.

2. The government and research centers should give attention on study and release of cultivars that have resistant to diseases and pests.

3. The large gap on yield obtained in research center and farmer's land should be minimized. The breeders do not give attention when compare to cereals crops

4. This result being from single location, it is recommended for further testing in diverse environments to identify favorable environments for genotypes.

5. It needs further studies on field pea to identify and select genotypes that have important agronomic properties and use them in direct hybridization.

6. It should be worthwhile to study more available germplasm over years and locations to identify more accessions as well as to confirm the importance of the traits identified as predictors of yield.

\section{Appendix}

Table 8. Mean values of 12 characters of 36 field pea genotypes grown at Siannas.

\begin{tabular}{|c|c|c|c|c|c|c|c|c|c|c|c|c|}
\hline No. Accessions & DE & DFI & DF & DM & PH & PPP & SPP & PL & ABG & YPP & HSW & HI\% \\
\hline 1. FP-32030 & 8 & 64 & 76 & 147 & 208 & 17.2 & 5.6 & 5.2 & 3000 & 18.8 & 12.1 & 33 \\
\hline 2. FP-237061 & 7 & 54 & 66 & 146 & 200 & 17.8 & 5.4 & 5 & 2000 & 12 & 12.9 & 45 \\
\hline 3. FP-32368 & 7 & 61 & 77 & 144 & 210 & 16.4 & 5.2 & 4.4 & 2200 & 19.2 & 14.5 & 45 \\
\hline 4. FP-32369 & 7 & 66 & 75 & 147 & 170 & 18 & 6.8 & 4.6 & 2300 & 18.2 & 13.7 & 43 \\
\hline 5. FP-32370 & 9 & 65 & 78 & 147 & 180 & 17 & 7.8 & 4.4 & 3000 & 20.2 & 12.5 & 36 \\
\hline 6. FP-32390 & 7 & 55 & 67 & 135 & 177 & 19 & 6 & 4.8 & 2560 & 18 & 13.6 & 50 \\
\hline 7. FP-32453 & 9 & 65 & 70 & 130 & 175 & 18 & 5.6 & 3.8 & 2900 & 11.9 & 14.1 & 40 \\
\hline 8. FP-32473 & 9 & 59 & 72 & 130 & 177 & 18.8 & 5.6 & 4.8 & 2450 & 8.2 & 12.3 & 33 \\
\hline 9. FP-202284 & 7 & 63 & 77 & 130 & 216 & 19.9 & 5.6 & 4.2 & 2450 & 10 & 13.9 & 41 \\
\hline 10. FP-32489 & 6 & 57 & 68 & 130 & 154 & 18.2 & 4.6 & 4.6 & 2850 & 8.8 & 14.3 & 33 \\
\hline 11. FP-244799 & 7 & 63 & 77 & 132 & 193 & 19.8 & 6 & 4.4 & 2460 & 8.1 & 14.9 & 59 \\
\hline 12. FP-32494 & 6 & 65 & 75 & 131 & 190 & 19.6 & 6.2 & 4.8 & 2450 & 8.4 & 12.6 & 43 \\
\hline 13. FP-32506 & 7 & 60 & 77 & 133 & 190 & 19.4 & 5.4 & 4.4 & 3200 & 18.8 & 14 & 34 \\
\hline 14. FP-32508 & 7 & 55 & 75 & 134 & 191 & 20.2 & 6.2 & 5.2 & 2600 & 7.9 & 15.4 & 40 \\
\hline 15. FP-32526 & 6 & 55 & 65 & 133 & 181 & 21.4 & 5.4 & 4.8 & 3000 & 8.4 & 12.1 & 49 \\
\hline 16. FP-237508 & 7 & 59 & 67 & 131 & 179 & 21.8 & 5.8 & 4.4 & 2900 & 9 & 13.8 & 34 \\
\hline 17. FP-32534 & 7 & 57 & 69 & 131 & 191 & 21.2 & 5.6 & 3.6 & 2700 & 12.2 & 11.7 & 48 \\
\hline 18. FP-32730 & 9 & 58 & 67 & 131 & 182 & 23.2 & 5.4 & 4.4 & 2600 & 9.1 & 12.2 & 40 \\
\hline 19. FP-32730 & 10 & 53 & 70 & 134 & 171 & 23.2 & 6 & 4.2 & 2760 & 8 & 12.6 & 40 \\
\hline 20. FP-212982 & 7 & 54 & 65 & 131 & 191 & 19 & 7 & 4.6 & 2640 & 8.7 & 13.2 & 34 \\
\hline 21. FP-219988 & 8 & 57 & 66 & 132 & 168 & 17.4 & 5.8 & 4.2 & 2550 & 18.2 & 14.7 & 45 \\
\hline 22. FP-223233 & 9 & 54 & 66 & 133 & 181 & 20.6 & 5.6 & 4.4 & 2450 & 11.9 & 14.1 & 46 \\
\hline 23. FP-223234 & 12 & 58 & 69 & 132 & 181 & 23.2 & 6.4 & 4.4 & 2650 & 20.8 & 13.8 & 37 \\
\hline 24. FP-223235 & 7 & 53 & 72 & 134 & 190 & 24.4 & 5 & 4.2 & 2750 & 11.5 & 13.9 & 38 \\
\hline 25. FP-244801 & 7 & 60 & 64 & 133 & 199 & 16.4 & 5.6 & 5 & 2820 & 14.6 & 14.2 & 45 \\
\hline 26. FP-229217 & 8 & 58 & 69 & 142 & 176 & 14 & 4.2 & 4.8 & 2780 & 11 & 12.8 & 32.5 \\
\hline 27. FP-234052 & 7 & 54 & 67 & 142 & 163 & 15.6 & 5 & 4 & 2460 & 9.2 & 12.1 & 43 \\
\hline 28. FP-234055 & 8 & 60 & 66 & 132 & 201 & 19.8 & 6 & 4.6 & 2490 & 11.4 & 12.5 & 54 \\
\hline 29. FP-235420 & 7 & 54 & 69 & 141 & 203 & 19.2 & 5 & 5 & 3200 & 12.4 & 13.7 & 37.5 \\
\hline 30. FP-235720 & 8 & 61 & 65 & 133 & 152 & 15.6 & 5.4 & 3.8 & 2300 & 11.14 & 12.9 & 41 \\
\hline 31. FP-237060 & 9 & 56 & 74 & 133 & 191 & 24.6 & 5.4 & 5.6 & 2610 & 10.6 & 14.3 & 47 \\
\hline 32. FP-241550 & 8 & 58 & 75 & 134 & 179 & 19.2 & 6.2 & 5 & 3200 & 20.3 & 15.8 & 53 \\
\hline 33. FP-237064 & 8 & 55 & 67 & 135 & 210 & 18.6 & 6.4 & 5.4 & 2580 & 18.8 & 17 & 40 \\
\hline 34. FP-229213 & 8 & 66 & 66 & 135 & 221 & 18.6 & 4.8 & 4.6 & 2540 & 18.4 & 11.3 & 47 \\
\hline 35. FP-32070 & 9 & 56 & 69 & 143 & 181 & 16.6 & 7 & 5 & 2530 & 20.4 & 17.1 & 38 \\
\hline 36. FP-238293 & 10 & 56 & 67 & 143 & 172 & 19.6 & 5.2 & 5.2 & 3000 & 10.5 & 16.1 & 40 \\
\hline Mean & 8.65 & 59.0 & 70.39 & 139.6 & 180.2 & 20.45 & 5.69 & 4.72 & 2726.4 & 11.43 & 13.87 & 41.69 \\
\hline $\mathrm{CV}$ & 15.15 & 5.63 & 5.52 & 2.6 & 6.21 & 11.99 & 12.6 & 8.82 & 19.42 & 18.0 & 7.0 & 15.0 \\
\hline LSD $(5 \%)$ & 2.7 & 6.7 & 7.9 & 7.4 & 18.7 & 4.9 & 1.46 & 0.85 & 14.6 & 6.4 & 1.92 & 17.6 \\
\hline
\end{tabular}

[2] Amare, G. and M. Adamu, 1994. Faba Bean and Field Pea Agronomy Research. In: Cool Season Food Legumes of Ethiopia, Tilaye, A. (Ed.). ICARDA., Alepo, Syria, pp: 199-227.

\section{References}

[1] Ali, M. A., Nawad, N. N. Abbas, A. Zulkiffal, M. and Sajjad, M, 2009. Evaluation of selection criteria in Field pea (Pisumsativum L.) using correlation coefficients and path analysis. Australian Journal Crop Science 3(2): 65-70.
[3] Ambrose, M. J., Ellis T. H. N., Flavell, A. J., 2010. The genetic diversity and evolution of field pea (Pisum) studied by high throughput retrotransposon based insertion polymorphism (RBIP) marker analysis. BMC Evolutionary Biology 10(1): 44. 
[4] Angaw, T. S. and W. Asnakew, 1994. Fertilizer Response Trials on High land Food Legumes. In: Cool-Season Food Legumes of Ethiopia, Asfaw, T. (Ed.). ICARDA. Alepo, Syria, pp: 279-292.

[5] Asfaw, T. D., Beyene and G. Tesfaye, 1994. Genetics and Breeding of Field Pea. In: Cool Season Food Legumes of Ethiopia, Asfaw, and T. (Ed.). ICARDA. Aleppo.

[6] Asfaw, Telaye, Tesfaye, Getachew and Beyene Demitsu (ed.). Cool-Season Food Legumes of Ethiopia. Proceeding of First National Cool-Season Food Legumes Review Conference, 16-20 December 1993, Addis Ababa, Ethiopia.

[7] Allard, R. W, 1996. Principles of plant breeding, John wilky and sores inc, New York.

[8] Asnke Fikre and Getu Geletu, 2004. Breading field pea for wider adaptation. Addis Ababa, Ethiopia. Sponserd by ICARDA.

[9] Ben-Zeíev, N. and D. Zohary, 1973. Species relationship in the Genus Pisum. Israel Journalbotany 22: 73-91.

[10] Burton, G. W. and E. H. Devance, 1953. Estimation of heritability in tall Festuca (Festucaarudindces) from replicated colonial material Agronomy J. 45, 78-481.

[11] Burton. G. W, 1952. Quantitative inheritance in grasses. Proceediology of the 6th international grass congress 1: 277-283.

[12] Ceyan, E. Kahraman A., Ates, M. K., Karadas, S., 2012). Stability analysis on seed yield and its components in peas. Bulgarian Journal of Agricultural sciences 18, 905-911.

[13] Cousin, R. A., Massager and A. Vingere, 1985. Breeding for Yield in Combining Peas. In: The Pea Crop: A Basis for Improvement, Hebbleth Waite, P. H., M. C. Heath., T. C. K. Dawkins (eds.). Butter worth, London, UK., pp: 115-129.

[14] Cochran., W. G. and G. M. Cox, 1957. Experimental Designs. $2^{\text {nd }}$ edition. John Wiley and Sons, Inc. New York, USA. Page: $648 \mathrm{p}$.

[15] CSA, 2002. Agricultural Sample Survey 2000/01. Report on Area and Production of Crops Private Peasant Holdings, Meher Season. Addis Ababa.

[16] CSA, 2008. Agricultural Sample Survey 2007/08. Report on Farm Management Practices. Private Peasant Holdings, Meher Season. Addis Ababa. vol. III.

[17] CSA, 2009. Agricultural Sample Survey 2008/09. Report on Farm Management Practices. Private Peasant Holdings, Meher Season. Addis Ababa. vol. III.

[18] CSA, 2010. Agricultural Sample Survey 2009/10 (2002 EC). Report on Area and Production of Crops Private Peasant Holdings, Meher Season. Addis Ababa. vol. IV.

[19] CSA, 2011. Agricultural Sample Survey 2010/11 (2003 EC). Report on Area and Production of Crops Private Peasant Holdings, Meher Season. Addis Ababa. vol. I.

[20] CSA, 2012. Crop production forecast sample survey. Report on area and production for major crops private peasant holdings, meher season. Addis Ababa, Ethiopia.

[21] Demisew Tesfaye, 2010. Genetic gain in seed yield and Associated Traits of Early and Medium Maturing of Soybean
[Glycine Max (L.) Merrill]. An M Sc. Thesis presented to the School of Graduates Studies of Haramaya University, Haramaya, Ethiopia.

[22] Dewey, D. R and K. Lu, 1959. Acorrelation and path coefficient analysis on components of ceated wheat grass seed production. Agronomic Journal, 51; 515-518.

[23] Dereje Gorfu and Tesfaye Bashir, 1994. Pea Diseases in Ethiopia. pp. 317-327. In: Asfew, Telaye, Tesfye Getachew and Beyene Demitsu (eds.). Cool Season Food Legumes of Ethiopia. Proceeding of First Cool Season Food Legumes Review Conference, 16-20 December 1993, Addis Ababa, Ethiopia.

[24] Duke, J. A., 1981. Hand book of legumes of world economic importance. Plenum Press, New York. p. 199-265.

[25] Ellis, T. H., N. Hofer J, Temmerman. Vaughan, G. M, Coyne, C. I, Hellenes R. p, 2011. Mendel 150 years on. Trends plant Sci. 16: 590-596.

[26] FAO, 1998. Recent developments in biotechnology as they relate to plant genetic resources for food and agriculture, by C. Spillane. Background Study Paper 9. Rome.

[27] FAO, 1998. The State of World's Plant Genetic Resources for Food and Agriculture. Food and Agriculture Organization, Rome, Italy.

[28] FAOSTAT, 2012. Available Online: http://faostat,fao.org/September, 29, 2013.

[29] Girma, B., 2003. The state of grain marketing in Ethiopia. Proceedings of the EDRI/IFPRI, 2020 Network Policy Forum on Toward Sustainable Food Security in Ethiopia: Integrating the Agri-Food Chain, May 15-16, 2003, Addis Ababa, Ethiopia Gilbert, Z. Gardening in South Africa, C. Struik, Cape Town, 1983.

[30] Girma Taye, Yohannes Tilahun and Meaza Demissie, 2002. Design and Analysis of Field Experiments in Agriculture. Technical Manual No. 15. Ethiopian Agricultural Research Organization. Addis Ababa, Ethiopia. pp 63-71.

[31] Grafus (1994). Genetic variability, correlation and path analysis studies in garden pea (Pisumsativum L.). Journal Agricultural Research 46(4): 333-340.

[32] ICARDA, 2011. International Center for Agricultural Research in Dry Areas, Aleppo, Syria.

[33] Johnson, H, W., H, F. Robinson and R. E Comstock 1955 Estimates of genetic and environmental variability in soy beans. Agronomy Journal, Society: 126-131.

[34] Johnson, H. W., H. F. Robinson and R, G, Cost tock, 1955. Genotypic and Phenotypic correlation Soya bean and their implication in Selection. Agronomy Journal v. 47: 477-483.

[35] Kalloo, G, 1988. Vegetables Breeding Vol. I. CRC press. inc. Bola Ration, Florida, 239P.

[36] Johnson, C. E and T. Hernadez, 1980. Heritability studies of early and total yield in field pea, Korti. SC 15: 280-285.

[37] Kebere Bezaweletaw, Ketema Belete and Prapa Sripichitt, 2006. Genetic Gain in yield potential and Associated Agronomic Traits in Haricot Bean (Phaseolus vulgaris L) Kasetsart Journal of Nature and Science. 40: 835-847. 
[38] Kebede Tadesse, 2006. Temporal development of stem rust (Puccini a graminisf. sp. tritici) and its effect on seed yield and protein contents of bread wheat in Bale, Ethiopia. An M Sc. Thesis presented to the School of Graduates Studies of Haramaya University, Haramaya, Ethiopia. 83p.

[39] Kemal Ali, Gemechu Keneni, Seid Ahmed, Malhotra, R. S., Beniwal, S. and Makkouk, K. (eds.). Food and Forage Legumes of Ethiopia: Progress and prospects. Proceeding of the workshop on food and forage legumes 22-26, September, 2003. Addis Ababa, Ethiopia. ICARDA, Aleppo Syria.

[40] Keneni Abinasa, Amsalu Ayana and Geremew Bultosa, 2005. Genetic variability, heritability and traits association infield pea (pisumsativum) genotypes.

[41] Khan, T. N. Ramzan., A. Jillani., G. Mehamood. T, 2013. Morphological performance of peas (Pisumsativum L.) Genotypes under Rain fed conditions of Potowar Region. J. Agric, Res., 51(10): 51-60.

[42] Manender Singh., S. Malik, Mukes Kumar., K. V. Singh., Sanjeev Kumar, Pavitra Devi, Vinuj Kumar, 2012. Studies of Variability, heritability and genetic advance in field pea (Pisumsativum L.) progressive Agriculture, 12(1); 219-222.

[43] Million, F., 2012. Variability, heritability and association o some morpho-agronomic traits in field pea (Pisumstivum L.) genotypes. Pakistan Journal. Biological. Science. 15: 358-366.

[44] Ministry of Agriculture and Rural Development (Mo ARD), 2006. Ministry of agriculture and rural development crop development department, crop variety register. Issue No. 9.

[45] Ministry of Agriculture and Rural Development (Mo ARD), 2010. Ministry of agriculture and rural development crop development department, crop variety register. Issue No. 19.

[46] Mulusew, F., Edossa, F., Tadele, T., and Teshome. L., 2009. Parametric stability analyses in field pea (Pisumsativum L.) under South Eastern Ethiopian Conditions. World Journal of Agricultural Science. 5 (2): 146-151.

[47] Mulusew, F., Tadele. T., Setegn. G., Bekele. H., 2010. Agronomic performance, disease reaction and yield stability of field pea (Pisumsativum L.) under South Eastern Ethiopian Conditions. Austraalian Journal Crops sciencces 4(4): 238246.

[48] Mussa Jarso, Tezera Wolabu and Gemechu Keneni, 2006. Review of field pea (Pisumsativum L.) genetics and breeding research in Ethiopia. pp. 67-85.

[49] Nawab, N. N, Subhani, G. M, Mahmood K, Shakil Q, Saeed A (2009). Genetic variability, correlation and path analysis studies in garden pea (Pisumsativum L.). Journal Agricultural Research 46(4): 333-340.

[50] Pandy and Tiwari. (1983) Variability, heritability and association of some morpho-agronomic traits in field pea (Pisumsativum L.) genotypes. Pakistan Journal Biological Science. 15: 358-366.

[51] Pan, Aaron D.; Jacobs, Bonnie F.; Herendeen, Patrick S. 2010. "Detarieaesensulato (Fabaceae) from the Late Oligocene (27.23 Ma) Guang River flora of north-western Ethiopia". Botanical Journal of the Linnean Society 163: 44-54.

[52] Ranjan, S., Kumar, M. and Pandey, S. S., 2006. Genetic variability in peas (Pisumsativum L.). Legume Research 29(4): 311-312.
[53] Pascal, 2004. "From pollen tubes to infection threads: Recruitment of Medicago floral pectic genes for symbiosis". The Plant Journal 39 (4): 587-98.

[54] Pesta, A., Titlow, A., Hansen, J., Berger, A., Furman, S., Luebbe, M., Erickson, G. and Jenkins, K. (2012). Effects of feeding field peas in combination with distiller grains plus soluble in finishing and growing diets on cattle performance and carcass characteristics. The Professional Animal Scientist 28(5): 534-540.

[55] Robertson. G. E., 1959. The sampling variance of genetic correlation coefficient Blo. 15; 469-485.

[56] Rasmusson, D. C and R, L Glass, 1967. Estimates of genetic and environmental variability in peas crop Science 185-188.

[57] Rodino A. P., Hernandez-Nistal J., Hermida M., Santalla M., De Ron A. M. (2009). Sources of variation for sustainable field pea breeding. Euphytica 166: 95-107.

[58] Sentayehu Alamrew, 2009. Assessment of nutrient contents of different pea genotypes (Pisumsativum L.) in Southwest Ethiopia. Ethiopian Journal of health Science 19 (3): 187-192.

[59] Sarikamis, G., Yanmaz, R., Ermis, S., Bakir M., Yuksel C., 2010. Genetic characterization of pea (Pisumsativum) germplasm from Turkey using morphological and SSR markers. Genetics and Molecular Research 9: 591-600.

[60] Singh, B. D. 1990. Plant breeding principle and methods. Kalian publishers Ludhiana new. Delhi.

[61] Slinkard, A. E., G. Bascur and G. Hernandez-Bravo. 1994. Biotic and abiotic stresses of cool season food legumes in the western hemisphere. p. 195-203. In: F. J. Muehlbauer and W. J.

[62] Kaiser (eds.), Expanding the Production and Use of Cool Season Food Legumes. Kluwer Academic Publisher. Dordrecht, The Netherlands.

[63] Santalla, M.; Amurrio, J. and De Ron, A. 2001. Food and feed potential breeding value of green, dry and vegetable pea germplasm. Canada Journal Plant Science. 8: 601-610.

[64] Singh. B. O, 1993 Plant breeding principles and methods. kalyani publishers Zudhlana. New Delhi.

[65] Singh, J. D. and Singh, I. P. 2004. Selection parameters for seed yield in field pea (Pisumsativum L.). National Journal Plant Improvement 6(1): 51-52.

[66] Singh, J. and Yadava, H. S., 2000. Factors determining seed yield in early generation of soybean. Crop Res. Hisar. 20: 239-243.

[67] Singh, B. O., 1990. plant breeding kalian, published new, Delli India 458P Toker, $\mathrm{C}$. and Cagirgan,

[68] M. I., 2004. The use of phenotypic correlations and factor analysis in determining characters for grain yield selection in chickpea (Cicer arietinum L.). Hereditas.

[69] Singh, M. Kumar, B., and Singh, J. P. Genetic variability, Heritability and character Association in Dwarf Field pea (Pisumsativum L.), progressive Agriculture, 2007, vol. 7, no. 1-2, pp. 102-104.

[70] Sharma, M. S., Rana, A., and Singh, Y. Genetic variability and Association studies for Green pod yield and component Horticultural Traits in Garden pea under High Hill Dry Temperature conditions, Indian Journal of Horticulture. 2007, vol. 64 , no. 4 , pp. $410-414$. 
[71] Temene Temesgen, 2008. Genetic gain and morpho-agronomic basis of genetic improvement in seed yield potential achieved by faba bean breeding in Ethiopia. An M Sc. Thesis presented to the School of Graduates Studies of Hawasa University, Hawasa, Ethiopia. 83p.

[72] Teshome Legese, 2011. Genetic Gain in Grain Yield and yield related traits of field pea (Pisumsativum L.) in Ethiopia. An M Sc. Thesis presented to the School of Graduates Studies of Haramaya University, Haramaya, Ethiopia. pp. 45-57.

[73] Tesfaye G (1999). Genetic variability and association of characters in some Ethiopian field pea (Pisumsativum L.) germplasm. M. Sc. Thesis. Alemaya University of Agriculture, Ethiopia.

[74] Tezera W (2000). Genotype x Environment interaction in Field pea (Pisumsativum L.) for yield and other traits across central and southern Ethiopia. M. Sc. Thesis. Alemaya University of Agriculture, Ethiopia.

[75] Togay, N., Y. Togay, B. Yildirin and Y. Dogan., 2008. Relationships between yield and some yield components in pea (Pisumsativumssparvense L.) genotypes by using correlation and path analysis. African Journal Biotechnology 7(23): 4285-4287. ISSN:
[76] Vander Maesen, L. J. G., W. J. Kaiser., G. A., Marx and M. Werede, 2011. Genetic basis for pulse crop improvement: collection, preservation, and genetic variation in relation to needed traits. In: R. J. Summerfield (ed.), World Crops: Cool Season Food Legumes. Kluwer Academic Publishers, Dordrecht, The Netherlands.

[77] Valov, J. K. and Smart, I. P. 1926. Phylogeny and taxonomy study for field pea (Pisumsativum L.). National Journal Plant Improvement 6(1): 51-52.

[78] Wright, S. 1921. Correlation and causation. Journal Agricultural Research. 20: 557-585.

[79] Yasin Goa and Mathewos Ashamo. Evaluation of field pea (Pisumsativum L.) genotypes performance for yield and yield components at five growing environments of southern Ethiopia, Areka Agricultural Research Center, Areka, Ethiopia. Current Research in Agricultural Sciences, 2014, 1(3), 65-76.

[80] Zakira. S., A. K. M., AIslam., M. K. Hasan Mitu and M. A. K. Milan, 2010. Genetic variability and character Association in Garden pea (Pisumsativum L.) genotypes. Pakistan Journal of science. Islamabad, Pakistan.

[81] Zohary, D. and Hopf, M. 1973. Domestication of pulses in the old world. Science. 